ПРОФЕСІЙНЕ ВИГОРАННЯ ТА ОСОБЛИВОСТІ КОПІНГ-СТРАТЕГІЙ АДВОКАТІВ

\title{
PROFESSIONAL BURNOUT AND FEATURES OF COPING STRATEGIES OF LAWYERS
}

У статті розкрито проблему просресійного вигорання серед адвокатів. Представлено теоретичний аналіз виявлення й усунення комплексу психологічних проблем, що ускладнюють виконання обов'язків адвокатом у рамках здійснення своєї просресійної діяльності. Перш за все че стосується проблеми професійного вигорання адвокатів. Профресійне вигорання адвокатів - че дуже поширене явище, до якого схильна більшість практикуючих адвокатів. Воно служить однією з головних причин розвитку професійної дефрормації та деструкції, що негативно позначається на есективності адвокатської діяльності. Зазначено актуальність чієї проблеми в контексті сучасних досліджень. Висвітлено результати емпіричного дослідження, які виявляють особливості профресійного вигорання та копінг-стратегій у адвокатів. Виявлено, що професійне вигорання за шкалою напруги, за шкалою резистентності та за шкалою виснаження характерне для вибірки адвокатів у всіх трьох фразах, а саме несфоормованій, стадії формування, ссрормованій. Виявлено, що у вибірці адвокатів використовуються різні копінг-стратегії, а саме стратегії вирішення проблем, пошуку соціальної підтримки, уникання проблем. Виявлено помірну негативну кореляцію між змінними «фаза напруги» та «вирішення проблем», помірну негативну кореляцію між змінними «раза резистентності» та «вирішення проблем», помірну негативну кореляцію між змінними «фраза виснаження» та «вирішення проблем», помірну негативну кореляцію між змінними «фраза напруги» та «пошук соціальної підтримки», помірну негативну кореляцію між змінними «фраза резистентності» та «пошук соціальної підтримки», помірну негативну кореляцію між змінними «фраза виснаження» та «пошук соціальної підтримки», слабку позитивну кореляцію між змінними «фраза напруги» та «уникання проблем», помірну позитивну кореляцію між змінними «фраза резистентності» та «уникання проблем», слабку позитивну кореляцію між змінними «фраза виснаження» та «уникання проблем». Робота спонукає до подальших досліджень, таких як більш детальне та об'ємне дослідження просресійного вигорання адвокатів різних практик; поглиблення дослідження взаємозв'язку просресійного вигорання з психологічною підтримкою та стратегіями поведінки адвокатів. Ключові слова: професійна діяльність, професійна деформація, ефрективна адво- катська діяльність, благополуччя юриста, психологічна підтримка.

The article presents the problem of professional burnout among lawyers. Theoretical analysis of identification and elimination of a complex of psychological problems that complicate the performance of duties by a lawyer in the framework of his professional activity is presented. First of all, it concerns the problem of professional burnout of lawyers. Professional burnout of lawyers is a very common phenomenon to which most practicing lawyers are prone. It is one of the main reasons for the development of professional deformation and destruction, which negatively affects the effectiveness of advocacy. The urgency of this problem in the context of modern research is indicated. The results of empirical research, which reveal the features of professional burnout and coping strategies in lawyers, are highlighted. It was found that professional burnout on the scale of stress, on the scale of resistance, and the scale of exhaustion is characteristic of the sample of lawyers in all three phases - unformed, in the stage of formation, in the formed phase. It was found that the sampling of lawyers uses different coping strategies, namely problem-solving, seeking social support, problem avoidance. There is a moderate negative correlation between the variables "voltage phase" and "problem-solving", a moderate negative correlation between the variables "resistance phase" and "problem-solving", a moderate negative correlation between the variables "phase depletion" and "problem-solving", a moderate negative correlation between variables "stress phase" and "search for social support", moderate negative correlation between variables "resistance phase" and "search for social support", moderate negative correlation between variables "phase of exhaustion" and "search for social support", weak positive correlation between "variables stress phase" and "problem avoidance", moderate positive correlation between the variables "resistance phase" and "problem avoidance", weak positive correlation between the variables "depletion phase" and "problem avoidance". The research encourages further research such as a more detailed and comprehensive study of the professional burnout of lawyers of different practices; deepening the study of the relationship between burnout and psychological support and behavioral strategies for lawyers.

Key words: professional activity, professional deformation, effective advocacy activity, well-being of a lawyer, psychological support.
Постановка проблеми. Проблема підвищення ефективності адвокатської діяльності має кілька шляхів вирішення. Один з них пов'язаний з виявленням та усуненням комплексу психологічних проблем, що ускладнюють виконання обов'язків адвокатом у рамках здійснення своєї професійної діяльності. Перш за все це стосується проблеми професійного вигорання адвокатів. Професійне вигорання - це дуже поширене явище, до якого схильна більшість практикуючих адвокатів. Воно служить однією з головних причин роз- 
витку професійної деформації та деструкції, що негативно позначається на ефективності адвокатської діяльності. Специфіка професійної діяльності адвокатів характеризується постійними контактами з різними людьми, пов'язана $з$ емоційною та інтелектуальною напругою, відповідальністю, що сприяють виникненню професійного вигорання.

У психології професійне вигорання розглядається як системна якість суб'єкта праці, яка проявляється в негативних психічних станах, процесах, відносинах і диспозиційних установках щодо себе, суб'єктів та об'єктів діяльності, в деформації професійної спрямованості у вигляді смислового відчуження та ресурсно руйнуючих копінг-стратегій [1]. Професійне вигорання $\epsilon$ відображенням регресивних тенденцій в особистісно-професійному розвитку, «збіднення» й навіть повного зникнення деяких професійно важливих властивостей суб'єкта діяльності.

Аналіз останніх досліджень і публікацій. Дослідженню професійного вигорання присвячені численні праці вітчизняних та зарубіжних науковців, зокрема Т.В. Зайчикової, Л.М. Карамушки, С.Д. Максименка, Б.П. Лазоренка, Т.М. Титаренко, В.В. Барабанщикової, В.В. Бойка, Н.Є. Водоп'янової, О.С. Старченкової, К. Армстронг, Дж. Коллінз, С. Гінзбург, Г. Діон, М. Лейтер, С. Джексона.

Термін «професійне вигорання» ввів X. Фреденберг для характеристики психічного стану здорових людей, що інтенсивно спілкуються з клієнтами в емоційно навантаженій атмосфері у процесі надання професійної допомоги [8].

К.В. Маслач визначає професійне вигорання як синдром фізичного та емоційного виснаження, виокремлює такі його складові частини, як розвиток негативної самооцінки, пасивне ставлення до роботи, втрата розуміння й співчуття. Він зазначає, що професійне вигорання - це не втрата творчого потенціалу, аемоційневиснаження, щовиникаєнатлістресу у процесі міжособистісного спілкування [6].

Питання про психологічний стан юристів, особливо адвокатів, вперше висвітлили у США через перманентно зростаючі звернення представників цієї спеціальності по психологічну допомогу. 3 80-х рр. минулого століття було проведено величезну кількість досліджень, присвячених вивченню стресу в професійній діяльності юриста, різних видів залежностей серед юристів, кількості самогубств та депресивних розладів. Наведемо найбільш цікаві, на наш погляд, зарубіжні дослідження в цій сфері з різних держав і різні за часом проведення.

Проблема професійного вигорання нині привертаєвсебільшуувагудослідниківзогляду на високу практичну значущість та недостатню розробленість. Практична значущість проблеми полягає в тому, що процеси профе- сійного психічного вигорання обов'язково негативно відображаються на ефективності і надійності здійснюваної професійної діяльності, знижують інтерес до самої діяльності, змінюють систему відносин суб'єкта діяльності.

Серед сучасних досліджень актуальними та соціально значущими є проблеми психологічного благополуччя працівників сфери юриспруденції, зокрема адвокатів.

Дослідження, проведене в Австралії у 2016 р., показало, що порівняно з іншими фахівцями юристи страждають від нижчого рівня психологічного та психосоматичного благополуччя. Зокрема, було виявлено, що зловживання психоактивними речовинами у юристів зустрічається в два рази частіше, ніж у представників інших професій. Крім того, в рамках дослідження зазначалося, що в юридичних фірмах поширена проблема залякування, зазначалося, що 58,4\% адвокатів хоча б один раз піддавалися шантажу і залякування під час своєї роботи [11].

Дослідження канадських учених показують, що юристи тим частіше стикаються 3 проблемами психічного здоров'я, чим успішніше в галузі своєї діяльності. У дослідженні Університету Торонто, яке провів Д. Колтай, порівнюються два національні опитування тисяч юристів, проведених у Канаді і Сполучених Штатах. В обох країнах дослідники виявили сильну кореляцію між ознаками депресії і традиційними показниками кар'єрного успіху. Адвокати, які працюють у великих компаніях приватного сектору, які вважаються найбільш престижними, найчастіше відчували депресивні симптоми. Дослідження Д. Колтая показало, що чим більше фірма і чим вище посада, тим більше ймовірність того, що у адвоката з'являться симптоми депресії [10].

Щорічні дослідження Товариства юристів Великобританії проводяться задля визначення рівня стресу у юристів на займаних ними посадах. Крім того, дослідження необхідні для того, щоб допомогти виявити основну проблему, яка провокує стрес, та мінімізувати ії. Останнє проведене дослідження показало, що 90\% молодих юристів говорять про постійний стрес і тиск на робочому місці, а більше половини з них вважають, що в результаті вони не зможуть впоратися з цією проблемою самостійно. У зв'язку з цим Товариство юристів Великобританії планує випустити керівництво для роботодавців із найкращої практики підтримки юристів та інших співробітників [10].

Дослідження, проведені в Північній Америці, показують, що юристи страждають від депресії в два рази частіше, ніж населення загалом, а також у три рази частіше, ніж працівники інших сфер. Це ж дослідження показало, що юристи в два рази частіше стають алкозалежними і думають про самогубство. 
Крім того, було відзначено, що юристи частіше звертаються до безрецептурних ліків та алкоголю, щоби впоратися зі своїми депресивними симптомами, ніж їх однолітки з інших професійних сфер; отже, кожен третій займається самолікуванням [7].

В іншому дослідженні, проведеному в Канаді, Дж. Воллес вивчав особисті, сімейні та професійні життєві вимоги, а також стратегії, які використовуються для задоволення цих вимог. У дослідженні взяв участь 121 юрист із великих і середніх канадських юридичних фірм [12; 13]. Отримані дані показали, що респонденти завжди ставили свою професійну діяльність як свій основний пріоритет, тому вони зазвичай працювали в середньому по 50 годин на тиждень, що часто включало нічний час та вихідні. Таке перевантаження являло собою одну 3 головних стресових загроз у їх житті. Вони відчували себе незадоволеними тим фактом, що ця ситуація не дає їм змогу приділяти достатньо часу відпочинку в колі сім'ї. Щоби впоратися зі стресом, який викликає професія, зазвичай використовувалися стратегії пошуку соціальної підтримки з боку сім'ї та друзів.

У 2017 р. Американською асоціацією юристів був опублікований маніфест під назвою «Національний проєкт - благополуччя юриста», який базується на наукових дослідженнях. В одному з них [9] стверджується, що, згідно з результатами опитування, у якому взяли участь майже 13 тис. адвокатів (юристів), які практикували на момент дослідження, від 21\% до 36\% респондентів мали проблеми з алкоголем, приблизно 28\% боролися з депресією, 19\% - з підвищеним рівнем тривожності, 23\% - зі стресом. Ці факти свід- чать про наявність регресивних тенденцій, що ведуть до професійного вигорання. На підставі дослідження було прийнято рішення про створення однойменного об'єднання «Національний проєкт - благополуччя юриста», завданням якого визнано поліпшення психологічного стану адвокатської спільноти.

На основі теоретичних і практичних напрацювань у психології, соціології, медицині для Асоціації були складені методичні рекомендації, програми навчання й допомоги адвокатам. 3 іх використанням проводяться тренінги, вебінари та інші заходи для досягнення мети, якою $€$ комплексне благополуччя юриста. Таким чином, накопичені знання конвертуються в практичні позитивні копінг-стратегії.

Постановка завдання. Метою статті $€$ аналіз особливостей професійного вигорання адвокатів, визначення взаємозв'язку професійного вигорання та копінг-стратегій.

Виклад основного матеріалу дослідження. $\mathrm{y}$ дослідженні взяли участь 30 адвокатів, практикуючі у сфері кримінального та некримінального права. Стаж роботи адвокатів становить від 2 до 6 років. Як діагностичний інструментарій було використано такі дві методики, як методика «Діагностика рівня професійного вигорання» В.В. Бойка [2] та методика «Індикатор копінг-стратегій», розроблена Д. Амірханом [5]. Для статистичної обробки даних було використано методи описової статистики та кореляційний аналіз (коефіцієнт кореляції Спірмена).

За методикою «Діагностика рівня професійного вигорання» ми отримали такі результати (рис. 1). За шкалою напруги у 24 досліджуваних відзначена несформована фаза напруги. Це говорить про те, що адвокати добре відчува-

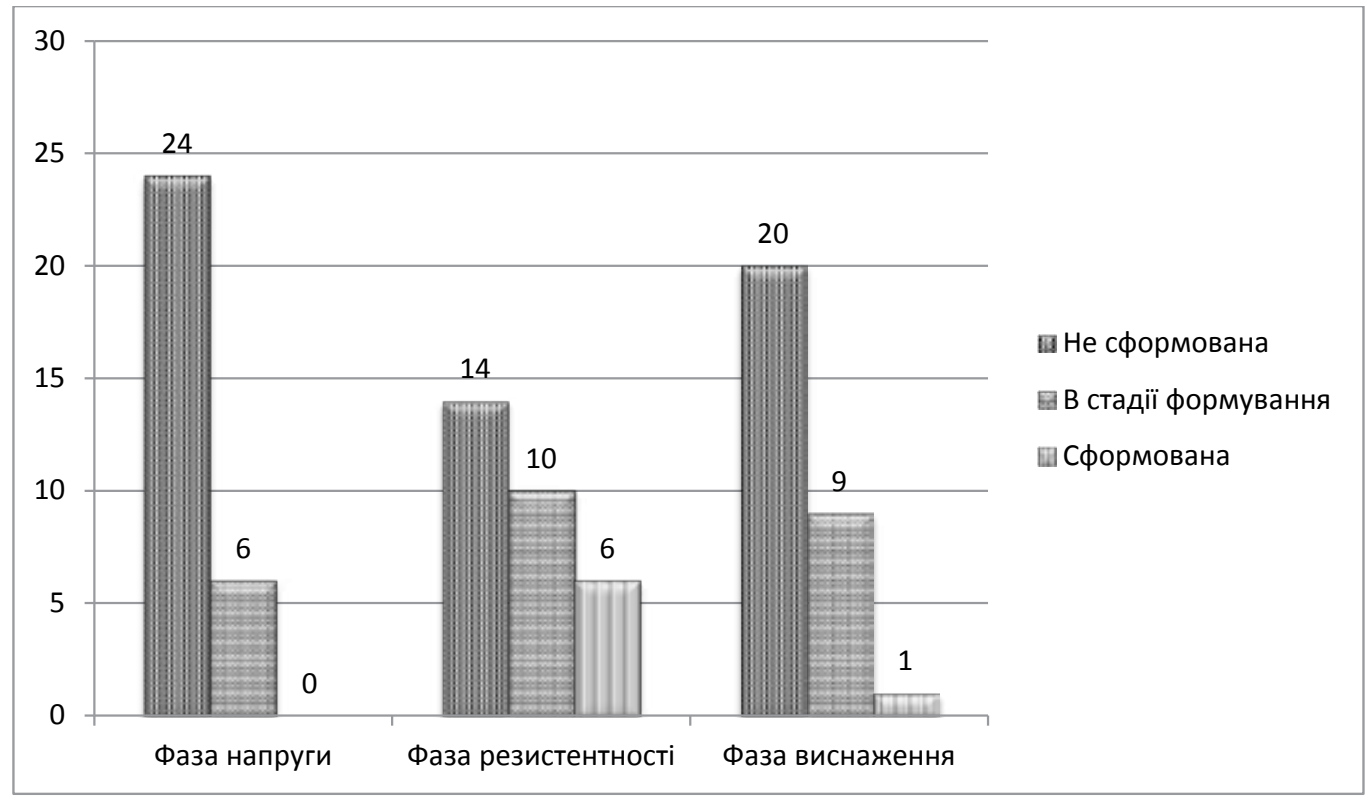

Рис. 1. Фази професійного вигорання (кількість працівників) 
ють себе на робочому місці, отримують позитивні емоції від робочого процесу, колективу, відчувають свою впевненість. У 6 адвокатів відзначається напруга як фактор емоційного вигорання у стадії формування, респонденти нерідко відчувають себе некомфортно на робочому місці, невдоволені собою, не отримують позитивних емоцій. Досліджуваних зі сформованою фазою напруги не виявлено.

За шкалою резистентності 14 респондентів мають несформовану фазу, і це говорить про те, що працівники намагаються знизити тиск зовнішніх обставин на свій емоційний стан, прагнуть до психологічного комфорту. У 10 досліджуваних виявлена резистентність у стадії формування, адвокати прагнуть мінімізувати свої емоції, намагаються скоротити або зменшити важкі обов'язки, які вимагають емоційних витрат, нерідко обділяють оточуючих елементарною увагою. Сформовану фазу виявлено у 6 адвокатів, і це свідчить про те, що вони виявляють емоційну черствість, нечемність, байдужість, обмежують емоційну віддачу, дуже часто така емоційна стриманість і закритість перетворюється в домашньому колі на агресію щодо рідних.

За шкалою виснаження несформована фаза зафіксована у більшості адвокатів (20 осіб), і це говорить про те, що досліджувані відчувають себе цілком комфортно на робочому місці, вони здатні до продуктивної роботи, відчувають у собі емоційні сили для діяльності. У 9 респондентів виснаження як фактор емоційного вигорання перебуває у стадії формування, це говорить про те, що у адвокатів емоційні контакти можуть викликати напругу, їм стає складно адекватно сприймати вимоги.
У 1 людини виявлено сформовану фазу виснаження, досліджуваний відчуває постійний стрес, що супроводжується поганим настроєм, почуттям страху, загостренням хронічних захворювань.

За методикою «Індикатор копінг-стратегій» ми отримали такі результати (рис. 2):

- копінг-стратегія «вирішення проблем» у адвокатів перебуває на середньому рівні $(24,33)$; це активна поведінкова стратегія, за якої людина намагається використовувати всі наявні у неї особистісні ресурси для пошуку можливих способів ефективного вирішення проблеми;

- копінг-стратегія «пошук соціальної підтримки» у адвокатів перебуває на середньому рівні $(19,74)$; це активна поведінкова стратегія, за якої людина для ефективного вирішення проблеми звертається по допомогу й підтримку до навколишнього середовища, а саме сім'ї та друзів;

- копінг-стратегія «уникання проблем» уадвокатів перебуває на низькому рівні $(18,12)$; це поведінкова стратегія, за якої людина намагається уникнути контакту з навколишньою дійсністю, піти від вирішення проблем.

Найбільш ефективним $є$ використання всіх трьох поведінкових стратегій залежно від ситуації. Іноді людина може самостійно впоратися з труднощами, іноді ій потрібна підтримка оточуючих, деколи вона просто може уникнути проблемну ситуацію, заздалегідь подумавши про її негативні наслідки.

Для того щоб виявити взаємозв'язок між факторами двох методик, такими як вирішення проблем, пошук соціальної підтримки, уникання проблем, фаза напруги, фаза резис-

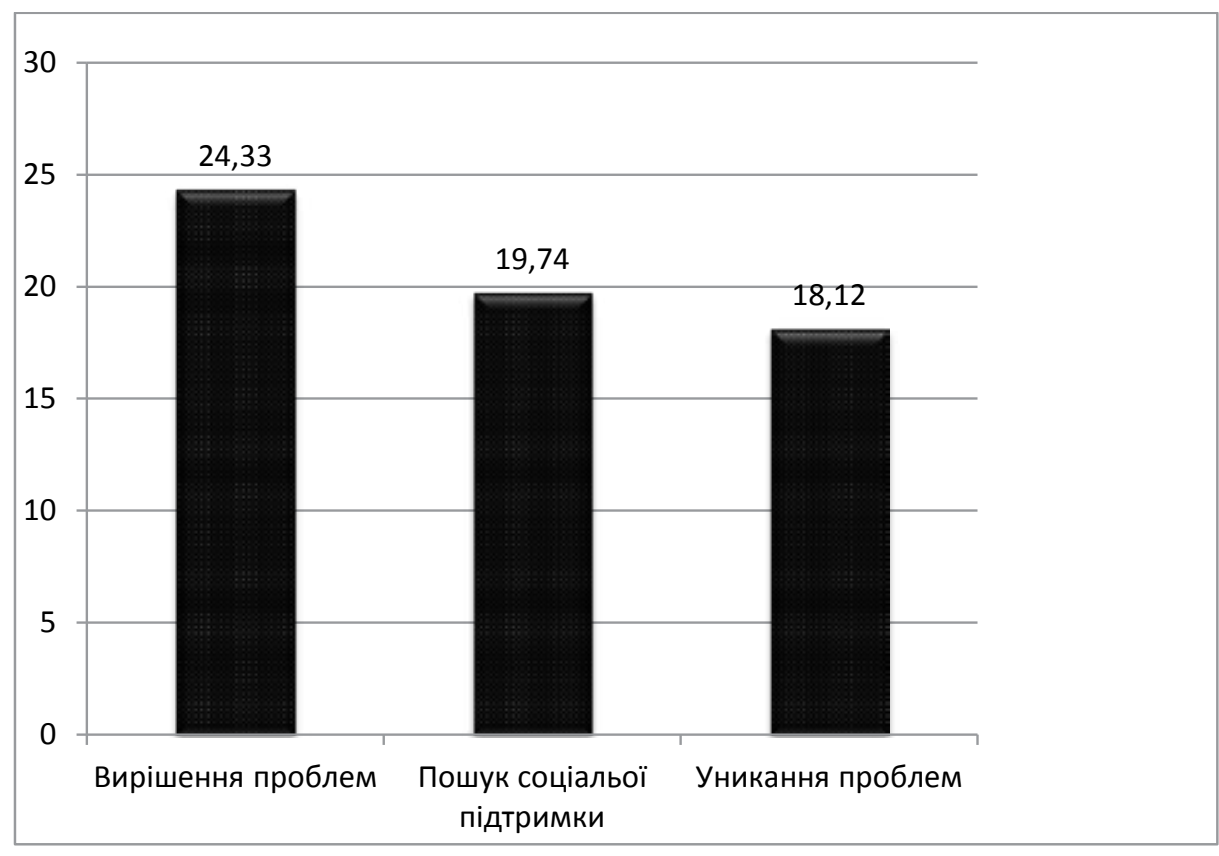

Рис. 2. Показники прояву копінг-стратегій 
Кореляційний аналіз (коефіцієнт кореляції Спірмена)

Таблиця 1

\begin{tabular}{|l|l|l|l|}
\hline Фаза & Вирішення проблем & $\begin{array}{l}\text { Пошук соціальної } \\
\text { підтримки }\end{array}$ & Уникання проблем \\
\hline Фаза напруги & $-0,578^{\star \star}$ & $-0,432^{\star \star}$ & $0,289^{\star}$ \\
\hline Фаза резистентності & $-0,522^{\star \star}$ & $-0,414^{\star \star}$ & $0,470^{\star \star}$ \\
\hline Фаза виснаження & $-0,501^{\star \star}$ & $-0,409^{\star \star}$ & $0,313^{\star \star}$ \\
\hline
\end{tabular}

* кореляція $є$ значущою на рівні 0,05;

** кореляція $€$ значущою на рівні 0,01

тентності, фаза виснаження, використаємо кореляційний аналіз (коефіцієнт кореляції Спірмена). Результати кореляційного аналізу наведені у табл. 1.

У процесі кореляційного аналізу було виявлено такі статистично значущі взаємозв'язки.

1) Помірна негативна кореляція між змінними «фаза напруги» та «вирішення проблем» $\left(-0,578^{\star \star}, p=0,002\right)$, тобто чим нижчий рівень фази напруги, тим вищий рівень вирішення проблем, і навпаки. Це пояснюється тим, що менш напружена людина здатна до кращого вирішення будь-яких питань.

2) Помірна негативна кореляція між змінними «фаза резистентності» та «вирішення проблем» $\left(-0,522^{\star \star}, p=0,005\right)$, тобто чим нижчий рівень фази резистентності, тим вищий рівень вирішення проблем, і навпаки. Це можна пояснити тим, що безпосередня участь у роботі та значний емоційний ресурс допомагають людині знаходити різні варіанти вирішення завдань та проблем.

3) Помірна негативна кореляція між змінними «фаза виснаження» та «вирішення проблем» $\left(-0,501^{\star \star}, p=0,007\right)$, тобто чим нижчий рівень фази виснаження, тим вищий рівень вирішення проблем, і навпаки. Це пояснюється тим, що менш виснажена людина здатна до ефективнішого вирішення проблем.

4) Помірна негативна кореляція між змінними «фаза напруги» та «пошук соціальної підтримки» $\left(-0,432^{\star \star}, p=0,001\right)$, тобто чим нижчий рівень фази напруги, тим вищий рівень соціальної підтримки, і навпаки. Можна це пояснити тим, що людина, яка не відчуває себе вкрай напружено, ймовірніше, зможе звернутися по допомогу до колег або друзів.

5) Помірна негативна кореляція між змінними «фаза резистентності» та «пошук соціальної підтримки» $\left(-0,414^{\star \star}, p=0,004\right)$, тобто чим нижчий рівень фази резистентності, тим вищий рівень соціальної підтримки, і навпаки. Це можна пояснити тим, що наявність у людини емоційного ресурсу та відсутність втоми від контактів сприяють її зверненню до оточуючих.

6) Помірна негативна кореляція між змінними «фаза виснаження» та «пошук соціальної підтримки» $\left(-0,409^{\star *}, p=0,006\right)$, тобто чим нижчий рівень фази виснаження, тим вищий рівень соціальної підтримки, і навпаки. Пояснюється це тим, що людина, яка не відчуває себе занадто виснажено, ймовірніше, зможе звернутися по допомогу до оточення.

7) Слабка позитивна кореляція між змінними «фаза напруги» та «уникання проблем» $\left(0,289^{*}, p=0,012\right)$, тобто чим вищий рівень фази напруги, тим вищий рівень уникання проблем, і навпаки. Це може означати, що наявність напруження спонукає людину до уникання проблем.

8) Помірна позитивна кореляція між змінними «фаза резистентності» та «уникання проблем» $(0,470 * \star, p=0,007)$, тобто чим вищий рівень фази резистентності, тим вищий рівень уникання проблем, і навпаки. Пояснюється це тим, що економія емоцій та зведення контактів до мінімуму аналогічно зводять до мінімуму бажання людини вирішувати будь-яку проблему, приводячи до уникання.

9) Слабка позитивна кореляція між змінними «фаза виснаження» та «уникання проблем» $\left(0,313^{\star *}, p=0,008\right)$, тобто чим вищий рівень фази виснаження, тим вищий рівень уникання проблем, і навпаки. Це можна пояснити тим, що виснажена людина не здатна розв'язувати всі проблеми. Інколи навіть уникання проблем відбувається не усвідомлено.

Висновки 3 проведеного дослідження. Проаналізовано особливості професійного вигорання адвокатів, визначено взаємозв'язок професійного вигорання та копінг-стратегій.

Професійне вигорання за шкалою напруги у більшості адвокатів з нашої вибірки виявлено у несформованій фазі. Досліджуваних зі сформованою фазою напруги не виявлено. За шкалою резистентності досліджувані поділились майже порівну, менша частина адвокатів має сформовану фазу. За шкалою виснаження несформована фаза зафіксована у більшості адвокатів.

Копінг-стратегії «вирішення проблем» та «пошук соціальної підтримки» на середньому рівні. Копінг-стратегія «уникання проблем» має показник низького рівня.

Виявлені взаємозв'язки між змінними професійного вигорання та копінг-стратегіями. Загалом ці взаємозв'язки демонструють, що адвокат, який менш напружений, менш виснажений, має емоційний ресурс та не мінімізує 
контакти з оточуючими, буде користуватися ефективними копінг-стратегіями у своїй професійній діяльності та особистому житті.

Базуючись на результатах емпіричного дослідження і вивченні теоретичного матеріалу, ми виявили особливості професійного вигорання адвокатів та взаємозв'язки професійного вигорання 3 копінг-стратегіями. Перспективи подальших досліджень вбачаємо у більш детальному та об'ємному дослідженні професійного вигорання адвокатів різних практик, а також поглибленні дослідження взаємозв'язку професійного вигорання та психологічної підтримки і стратегій поведінки адвокатів.

\section{ЛІТЕРАТУРА:}

1. Бойко В.В. Психоэнергетика. Санкт-Петербург : Питер, 2008. 416 c.

2. Ильин Е.П. Психология индивидуальных различий. Санкт-Петербург : Питер, 2004. 701 с.

3. Маслач К.В. Профресійне вигоряння: як люди справляються. URL: http://www.top-personal.ru.
4. Costa M., Ferreira M. Fontes e Reações de Estresse em Advogados Brasileiros. Paidéia. 2014. Vol. 24 (57). P. 49-56.

5. Freudenberger H.J. Staff burn-out. Journal of Social Issues. 1974. P. 159-166.

6. Krill P.R., JD, LLM; Johnson R., MA; Albert L., MSSW. The Prevalence of Substance Use and Other Mental Health Concerns Among American Attorneys. Journal of Addiction Medicine. 2016. No 10 (1). P. 46-52. DOI: 10.1097/ADM.0000000000000182.

7. Kriti P., Jayashree N., R. Shekhar S Occupational Stress and Burnouts as Predictors of Job Satisfaction Amongst Lawyers in District Sangli. National journal of medical research. 2012. Vol. 2. P. 141-144.

8. Leignel S., Schuster J.-P., Hoertel N., Poulain X., Limosin F. Mental health and substance use among self-employed lawyers and pharmacists. Occupational Medicine. 2014. Vol. 3. P. 166-171.

9. Wallace J.E., Joudrey A.D. Leisure as a coping resource: A test of the job demand-control-support model. Human Relations. 2009. Vol. 2. P. 5-15.

10. Wallace J.E. Juggling it all: Exploring lawyer's work, home, and family demands and coping strategies: Report of stage on findings. Newton, PA : Law School Admission Council, 2002. 69 p. 